\title{
DECREASE IN PRODUCTION AND QUALITY OF GRAIN DUE TO NECK BLAST DISEASE IN SOME LOWLAND RICE VARIETIES
}

\author{
Subiadi, Surianto Sipi, \& Fransiska R.A. Basundari \\ West Papua Assessment Institute for Agricultural Technology, Indonesia \\ JL. Brigjen Marinir (Purn) Abraham O. Atururi \\ Regional Government Office Complex of West Papua Province, Arfai, Manokwari 98315 \\ E-mail : surianto.sipi@gmail.com
}

\begin{abstract}
Decrease in production and quality of grain due to neck blast disease in some lowland rice varieties. Neck blast disease of rice causes a decrease in yields both in quantity and quality. The study was conducted to see the effect of neck blast disease on the characteristics of grain and yields of several high yielding varieties of lowland rice. The varieties used were Ciherang, Inpari 4, Inpari 7, Inpari 8, and Inpari 9. The parameters observed were the incidence and severity of neck blast disease, the ratio of the size of the seeds of healthy and sick panicles and the estimated production. The analysis showed that all varieties planted were infected by neck blast disease, but based on Disease Incident rate in the Necks, Ciherang and Inpari 8 varieties reacted susceptible to neck blast disease, Inpari 7 and 9 were moderate and Inpari 4 was resistant to neck blast disease. The quality of panicle grain infected by neck blast disease has decreased the size of grain width and was significantly different from grain of healthy panicles in all varieties. The highest estimated productivity was Inpari 4 variety of $10,378 \mathrm{~kg} / \mathrm{ha} \mathrm{which}$ experienced a decrease in production by $35.86 \%$ and the lowest was Ciherang variety of $8,367 \mathrm{~kg} / \mathrm{ha}$ which experienced a decrease in production by $48.37 \%$ when they were infected by neck blast disease.
\end{abstract}

Key words: characteristics of grain, neck blast, rice

\section{INTRODUCTION}

Blast disease is one of the important diseases in rice plants besides tungro disease. Originally blast disease in Indonesia was found in upland rice, but now it has also been found in lowland rice (Zulaika et al., 2018). This disease, which is able to reduce a great deal of yields, is caused by the pathogenic fungus Pyricularia grisae. Blast generates two typical symptoms, namely leaf blast and neck blast. The leaf blast is in blackish brown spots, rhombic-shaped, with white spots in the center. Meanwhile the neck blast is in the form of blackish brown spots at the base of the neck which can result in panicle neck unable to support panicles and broken. Neck blast disease is one of the main causes of rice yield loss (Hao et al., 2011). Plants infected by blast disease in the vegetative phase, most likely will experience infection in the panicle neck through transmission from leaf to panicle neck (Ghatak et al., 2013).

The occurrence of neck blast disease begins with the attachment of the fungus spore Pyricularia grisea Sacc. on the surface of the plant, in this case the panicle neck. Then the spores germinate. After that it is followed by the development of the sprout tube and the formation of the apresorium which then penetrate into the plant tissue (Galhano \& Talbot, 2011). The process of penetrating appressoria of $P$. oryzae on hard cell walls requires high turgor pressure and there is a correlation between turgor pressure resulting in appressoria and its ability to penetrate plant membranes (Dewi et al., 2013).

Besides being found in rice plants, this pathogen is also found in other cereal crops such as wheat, sorghum and more than 40 species of Graminae $(\mathrm{Ou}$, 1985). The yield loss that has been reported due to blast disease varies depending on location, cultivated varieties, planting season and cultivation techniques (Sudir et al., 2014).

Infection of blast pathogens in panicle neck can reduce the productivity and quality of grain produced. The results of study conducted by (Ahmadikhah \& Khosravi, 2018) stated that blast disease that infects rice plants can significantly reduce the weight of 100 grain seeds and produce more broken rice than healthy/ uninfected plants. The results obtained by Singh et al. (2013) highlighted that the increase in the percentage of blast disease infection in rice panicles can increase the percentage of empty grain, reduce the weight of 1000 seeds, and reduce the weight of results of 100 panicles.

The weight of 1000 seeds is one of the parameters that can be measured to determine the grain weight, 
where the grain weight is one of the 3 main components that determine crop yield besides the number of panicles per clump and the number of grain per panicle. Meanwhile, grain weight is positively correlated with the form of grain which is a combination of grain length, grain width, ratio of length and width of grain and thickness of grain (Abebrese et al., 2019; Huang et al., 2013).

It is estimated that yield loss due to blast disease every year reaches $10-30 \%$ of rice production worldwide (Skamnioti \& Gurr, 2009). The results obtained by Maheshwari \& Sharma (2013) showed that yield loss varies from 25.21 to $45.52 \%$ depending on location.

Based on this, a study was conducted to see the effect of neck blast disease on the decrease in grain production and quality in several high yielding varieties of lowland rice.

\section{MATERIALS AND METHODS}

Research Site. The high yielding rice varieties used in this study were Inpari 4, Inpari 7, Inpari 8, Inpari 9, and Ciherang. Inpari 4, Inpari 7, Inpari 8, and Inpari 9 varieties are high yielding potential varieties, while Ciherang is an existing variety which is frequently infected by blast disease in the field. The study was conducted in Sidey District of Manokwari Regency from March to July 2015. Sidey District is one of the locations whose fields are frequently infected by blast disease. The study was carried out on a farm area of 0.75 ha. The rice planting system used in this study was Legowo 6: 1 with $20 \times 20 \times 40 \mathrm{~cm}$ of planting space (without inserted plants). This way of planting gets a plant population of 30 clumps per $1.4 \mathrm{~m}^{2}(214,285$ clumps/ ha). The area of embankment in the rice fields where the research was carried out was $700 \mathrm{~m}^{2}$ in 1 ha $(7 \%)$ so the number of clumps/ha corrected was 199,285.

Disease Incident in the Necks/DIN. The Disease Incident in the Necks (DIN) was observed when rice panicles entered the physiological mature phase $( \pm 7$ days before harvest). DIN was calculated based on the comparison between the number of tillers whose panicles got neck blast disease, and the number of productive tillers per clump (Katsantonis et al., 2008; Hao et al., 2011). The number of productive tillers was determined by calculating the number of tillers that produced panicles per clump. The number of tillers infected by neck blast disease was determined by calculating the number of tillers per clump, whose panicles were infected by neck blast. The disease incident in the necks was calculated on each sample plant, which was 10 clumps per replicate (3 replications) expressed in percentage based on (Katsantonis et al., 2008) the following formula:

$$
D I N=\frac{P I}{N P} \times 100
$$

$\mathrm{NP}=$ Number of tillers that produce panicles per clump, PI $=$ The number of tillers with panicles infected by neck blast disease per clump.

Based on the DIN value, the varieties were grouped as resistant (R) if the DIN value is $0-15 \%$, moderate resistant (MR) if it is $15.1-30 \%$, moderate susceptible (MS) if it is $30.1-50 \%$, and susceptible (S) if the DIN value is $50.1-100 \%$ (Puri et al., 2009).

Panicle Blast Severity/PBS. The panicle blast severity was observed when rice panicles entered the physiological mature phase ( \pm 7 days before harvest). There were 30 -panicle samples ( 1 panicle per clump) from the healthy and the sick panicle group that were was taken randomly to measure of panicle blast severity.

The panicle blast severity is based on each scale of the disease in each panicle affected by IRRI (2013) with the following formula:

$$
\begin{aligned}
& \text { PBS }=\frac{(10 \times \mathrm{N} 1)+(20 \times \mathrm{N} 3)+(40 \times \mathrm{N} 5)+(70 \times \mathrm{N} 7)+(100 \times \mathrm{N} 9)}{\text { Total no. of Panicles Observed }} \\
& \text { PBS = Panicles Blast Severity } \\
& \mathrm{N}=\text { number of panicles with score 1-9 } \\
& 1=\text { Lessions on several pedicels or secondary } \\
& \text { branches } \\
& 3=\text { Lessions on a few primary branches or the } \\
& \text { middle part of the panicle axis } \\
& 5=\text { Lessions partially around the base (node) or }
\end{aligned}
$$

Grain Size and Estimated Result. The healthy panicle group and the blast-infected panicle group were taken from the field, shed and put into plastic ice per panicle. Filled grain and empty grain from each panicle were separated then calculated for the number of grain per panicle, percentage of empty grain per panicle, and weight of 1000 items. To see the ratio of grain size of the healthy panicle and blast-infected panicle, measurements of grain length and width were carried 
out on 100 grains from each group of healthy panicles and blast-infected panicles.

Estimated results of productivity from the condition of healthy plants and sick plants is determined by the component production variable with the formula of productivity $(\mathrm{kg} / \mathrm{ha})=($ number of clumps $/ \mathrm{ha}) \mathrm{x}$ (number of panicles) $\mathrm{x}$ (number of grains/panicle) $\mathrm{x}(\%$ of filled grain/panicle) $\mathrm{x}$ (weight of 1000 items (g)) $\mathrm{x}$ $\left(10^{-6}\right)$.

Data Analysis . Data of grain size from healthy and sick panicles were compared using the $t$ test, while data on Disease Incidents in the Necks (DIN) and Panicle Blast Severity (PBS) were analyzed using ANOVA with the SPSS program. Post Hoc tests were conducted with Duncan's at a level of accuracy of $95 \%$ if there were significant differences in the treatment tested.

\section{RESULTS AND DISCUSSION}

Disease Incidents in the Necks (DIN) and Panicle Blast Severity (PBS). The analysis of the Disease Incidents in the Necks (DIN) in lowland rice varieties tested in the field showed that one variety was susceptible to neck blast disease (Inpari 8), two varieties were moderate resistant (Inpari 9 and Inpari 7), one variety was resistant (Inpari 4), and one variety was susceptible (Ciherang). According to Suganda et al. (2016), Ciherang variety is a variety that is susceptible to blast disease.

The analysis of the Panicle Blast Severity showed that the Inpari 8 and Inpari 9 varieties were not significantly different from the existing variety (Ciherang); two other varieties, which were Inpari 4 and Inpari 7 showed severity that differed significantly from the existing variety and two other test varieties.

Based on the results in the field, it was found that all rice varieties planted were infected by neck blast. The highest disease incidence in the necks was $89.13 \%$ in Inpari 8 variety and the lowest was $11.67 \%$ in Inpari 4 variety. Likewise, the highest panicle blast severity was in Inpari 8 variety of $58.67 \%$ and the lowest one was in Inpari 4 variety of $32.67 \%$. For comparison, the results obtained by (Hai et al., 2007) presented that that the lowest range of disease incidence in the necks was $14.07 \%$ and the highest one was $74.79 \%$, while the lowest value of panicle blast severity was $10.58 \%$ and the highest one was $61.62 \%$.

These results indicate a difference in the response of the test varieties to the attack of neck blast disease both in incidence and severity. Inpari 4 variety that was categorized as resistant based on the incidence value of $11.67 \%$ (DIN value $0-15 \%=$ resistant) and the panicle blast severity of $32.67 \%$ whcih is lower than all observed samples, shows that Inpari 4 belongs to the resistant category but can still show symptoms of neck blast disease. Inpari 9 variety whose incidence value was $26.75 \%(15.1-50 \%$ DIN value $=$ moderate resistant $)$ had a high panicle blast severity, which was $55.67 \%$ (Tabel 1). This indicates that the disease incidence in the necks is not always linear with the panicle blast severity, because panicle blast severity describes the disease severity score per unit sample (score range of 0-9) while the disease incidence in the necks describes the presence or absence of disease incidene of neck blast disease in a group of samples.

The high rate of blast disease is due to susceptible varieties and or the emergence of new generations and races of blast disease (Khan et al., 2014). In addition, this disease can be contracted from seeds originating from previous plantings that are infected by blast disease (Faivre-Rampant et al., 2013). Climate conditions also have a major effect on the presence, development and pathogenicity in the field (Koutroubas et al., 2009).

Effect of Neck Blast Disease on Characteristics of Production Components. The results of this study indicate that the number of grains per panicle between healthy and sick panicles varied in each variety. Ciherang, Inpari 4, Inpari 7, and Inpari 9 variety had a higher number of grain per panicle in the healthy panicle group compared to blast-infected panicle group. On the other hand, Inpari 8 variety had a higher number of grains per panicle in blast-infected panicle group compared to the healthy panicle group (Table 2).

These results indicate that neck blast disease does not always negatively affect the number of grains. This is caused by pathogens of neck blast disease which usually infects panicles when the panicles are fully formed. Panicles have been formed during the pregnant phase, whose number depends on the genetic factors of each variety and/or environmental factors. The pathogens of neck blast disease which infects the panicles after they are completely formed no longer affect the amount of grain per panicle but will affect the grain filling (seeds).

The results of t-test analysis of the effect of neck blast disease on the number of empty grains, weight of 1000 grains, and grain weight per panicle of each test variety showed a significant difference between the healthy panicle group and neck-blast-infected panicle group (Table 3 - Table 5). 
The number of filled grain per panicle, the number of empty grains per panicle, and the weight of 1000 grains are indicators in predicting the productivity of a variety besides the number of productive tillers. Panicles infected by neck blast disease had higher number of empty grains per panicle and lower weight of 1000 grains than healthy panicles in all varieties, and based on t-test results it was found that all of these components had significantly different values between healthy panicles and neck-blast-infected panicles in all test varieties.

Ciherang and Inpari 8 varieties infected by neck blast with higher values in DIN panicle blast severity had a percentage of empty grain in sick panicles of $40.22 \%$ and $44.55 \%$ respectively and were higher compared to other varieties. Likewise, in Inpari 4 and Inpari 7 varieties with lower values in DIN and severity, they also had a lower percentage of empty grain in sick panicles of $30.27 \%$ and $26.72 \%$ respectively. These results indicate that the higher the rate of neck blast disease, the higher the number of empty grain in panicles. According to Wicaksono et al. (2017), symptoms of blast disease in the stem and panicle can inhibit or stop the flow of plant photosynthates. The results obtained by Singh et al., (2013) showed that if there is a blast infection in the panicle of $100 \%$, the empty grain will increase by $17.53 \%$, the weight of 1000 grain seeds will be reduced by $23.88 \%$ and the weight of 100 panicle yields will be reduced by $37.52 \%$.

Effect of Neck Blast Disease on Grain Size. Neck blast had a negative effect on the ratio of length to width of grain in all varieties tested. The ratio of length to width of grain (Ratio p/l) was higher in grain from panicles infected by neck blast disease compared to grain from healthy panicles for each variety and was significantly different based on $t$ test (Table 6). Inpari 8 variety which had the highest panicle blast severity (Table 1) also had the highest ratio of length to width of grain, which was 5.72. This shows that the higher the panicle blast severity, the higher the ratio of length to width of grain.

The quality of grain produced from plants infected by neck blast disease experienced a decrease in the size of the width of the grain and showed a significant difference between the grain from the healthy panicle group and that from neck-blast-infected panicle group in all test varieties (Table 6).

Table 1. Disease incidents in the necks and panicle blast severity naturally in the field

\begin{tabular}{ccc}
\hline Name of variety & DIN (\%) & PBS (\%) \\
\hline Ciherang & $73.20 \mathrm{c}$ & $54.33 \mathrm{c}$ \\
Inpari 4 & $11.67 \mathrm{a}$ & $32.67 \mathrm{a}$ \\
Inpari 7 & $46.48 \mathrm{~b}$ & $42.67 \mathrm{~b}$ \\
Inpari 8 & $89.13 \mathrm{c}$ & $58.67 \mathrm{c}$ \\
Inpari 9 & $26.75 \mathrm{ab}$ & $55.67 \mathrm{c}$ \\
\hline
\end{tabular}

The number followed by the same letter in the same column is not significantly different according to the Duncan's test at the level of 5\%; DIN $=0-15 \%$ (resistant); DIN $=15.1-50 \%$ (moderate resistant); DIN $=50.1-100 \%$ (susceptible)

Table 2.Effect of neck blast disease on the average number of grain per panicle (items) in Ciherang, Inpari 4, Inpari 7, Inpari 8 and Inpari 9 variety

\begin{tabular}{lccccc}
\hline \multirow{2}{*}{ Panicle status } & \multicolumn{5}{c}{ Varieties } \\
\cline { 2 - 6 } & Ciherang & Inpari 4 & Inpari 7 & Inpari 8 & Inpari 9 \\
\hline Healthy & 138.50 & 144.83 & 117.13 & 147.97 & 182.90 \\
Blast & 125.93 & 131.87 & 105.13 & 162.53 & 153.50 \\
t count value & 1.525 & 2.016 & 2.504 & 1.821 & 3.501 \\
t table value & 2.001 & 2.001 & 2.001 & 2.001 & 2.001 \\
Significant & $\mathrm{NS}$ & $*$ & $*$ & $\mathrm{NS}$ & $*$ \\
\hline
\end{tabular}

NS = Insignificantly Different; * = Significantly Different 
The length of grain in the Ciherang variety and Inpari 9 variety did not differ significantly between the healthy panicle group and neck-blast-infected panicle group. Even in Inpari 4 and Inpari 7 variety, the length of grain in neck-blast-infected panicles was higher than in healthy panicles. These results indicate that neck blast disease does not always negatively affect the length of grain but will negatively affect the width of grain. This happens because in general neck blast disease is found when the panicles are fully formed. The fully formed rice panicle has a maximum length of grain, while the width of grain depends on the process of seed filling. In Inpari 8 variety, the length of panicle grain infected by neck blast disease was lower and significantly different from healthy panicles caused by the very high panicle blast severity in Inpari 8 variety which the led to decrease in the length of grain length during measurement due to the higher of grain dryness rate in blast-infected panicles with a high score of severity (score 7 and 9).

Blast causes a negative effect on grain water content at harvest. At some severity rates, blast disease can cause prematurity in mature and dry grain. In these conditions the rate grain filling varies from empty to halffilled grain. This situation can affect the quality of rice from the mill. Consequently, it can reduce the head rice percentage and increase broken rice (Candole et al., 2000).

The healthier the panicle, the more the seed filling will have an impact on the width of the grain. Therefore, neck blast disease has no effect on the length grain but will affect the width of grain. Grain from healthy panicles has a wider size compared to blast-infected panicles.

Table 3. Effect of neck blast disease on the number of empty grain (\%) in Ciherang, Inpari 4, Inpari 7, Inpari 8 and Inpari 9 variety

\begin{tabular}{lccccc}
\hline \multirow{2}{*}{ Panicle status } & \multicolumn{5}{c}{ Varieties } \\
\cline { 2 - 6 } & Ciherang & Inpari 4 & Inpari 7 & Inpari 8 & Inpari 9 \\
\hline Healthy & 12.18 & 7.64 & 10.17 & 24.10 & 19.79 \\
Blast & 40.22 & 30.27 & 26.72 & 44.55 & 38.52 \\
t count value & 7.629 & 6.589 & 6.764 & 6.331 & 5.243 \\
t table value & 2.001 & 2.001 & 2.001 & 2.001 & 2.001 \\
Significant & $*$ & $*$ & $*$ & $*$ & $*$ \\
\hline
\end{tabular}

Table 4. Effect of neck blast disease on the weight of 1000 grains (\%) in Ciherang, Inpari 4, Inpari 7, Inpari 8 and Inpari 9 variety

\begin{tabular}{lccccc}
\hline \multirow{2}{*}{ Panicle status } & \multicolumn{5}{c}{ Varieties } \\
\cline { 2 - 5 } & Ciherang & Inpari 4 & Inpari 7 & Inpari 8 & Inpari 9 \\
\hline Healthy & 27.31 & 27.04 & 28.40 & 23.14 & 23.56 \\
Blast & 22.82 & 25.05 & 25.86 & 18.74 & 20.01 \\
t count value & 9.041 & 4.649 & 7.346 & 6.682 & 7.237 \\
t table value & 2.570 & 2.570 & 2.570 & 2.570 & 2.570 \\
Significant & $*$ & $*$ & $*$ & $*$ & $*$ \\
\hline
\end{tabular}

Table 5. Effect of neck blast disease on the grain weight per panicle (g) in Ciherang, Inpari 4, Inpari 7, Inpari 8 and Inpari 9 variety

\begin{tabular}{lccccc}
\hline \multirow{2}{*}{ Panicle status } & \multicolumn{5}{c}{ Varieties } \\
\cline { 2 - 6 } & Ciherang & Inpari 4 & Inpari 7 & Inpari 8 & Inpari 9 \\
\hline Healthy & 3.06 & 3.41 & 2.89 & 2.48 & 3.05 \\
Blast & 1.75 & 2.30 & 1.98 & 1.65 & 1.85 \\
t count value & 5.882 & 5.869 & 6.573 & 4.935 & 6.727 \\
t table value & 2.001 & 2.001 & 2.001 & 2.001 & 2.001 \\
Significant & $*$ & $*$ & $*$ & $*$ & $*$ \\
\hline
\end{tabular}




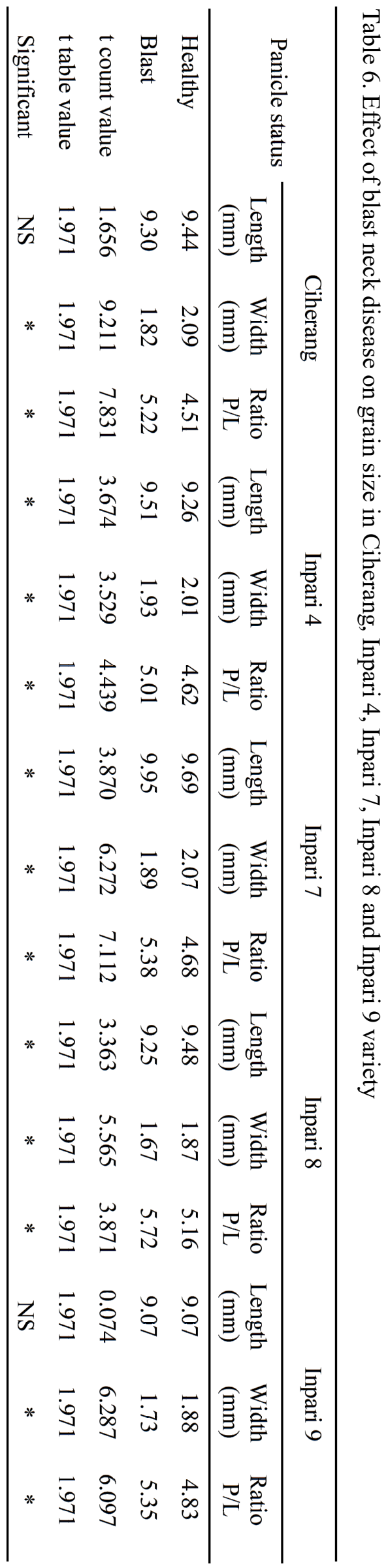

Effect of Neck Blast Disease on Harvest. The productivity of milled dry grain (GKG) in each variety was estimated based on production components (number of clumps/ha, number of panicles/clump, number of grains/panicle, $\%$ of filled grains/panicle, and weight of 1000 grains) between healthy panicles and neck-blastinfected panicles (Table 7). If all plants are assumed to be in the healthy category, then productivity can reach 8.3-10.3 tons/ha. However, if it is assumed that all plants are infected by neck blast disease, the productivity is between 4.3-6.6 tons/ha.

Productivity in the healthy plant group was higher than the productivity in the sick plant group and differed significantly. According to Mousanejad et al. (2010), the area of the blast disease on the leaves and the index value of the area of the blast disease correlate closely with the yield loss. The highest estimated productivity was Inpari 4 variety by $10.378 \mathrm{~kg} / \mathrm{ha}$ in the healthy panicle group and experienced a decrease in production by $35.86 \%$ when grouped into plants infected by neck blast disease. The lowest productivity was in Ciherang variety at $8.367 \mathrm{~kg} / \mathrm{ha}$ for healthy plant group and experienced a decrease in production by $48.37 \%$ for neck-blast-infected plant group. Neck blast disease in rice plants does not cause $100 \%$ yield loss, because the process of grain filling in panicles is still occurring even though it is not optimal, as is the case with healthy panicles (Subiadi et al., 2016).

\section{CONCLUSION}

All test varieties in this study were infected by neck blast disease, but based on DIN (Disease Incident in the Necks), Ciherang and Inpari 8 variety reacted susceptible to neck blast disease, Inpari 7 and 9 were moderate resistant, and Inpari 4 was resistant to neck blast disease. The quality of grain from plants infected by neck blast disease experienced a decrease in the width of grain and showed a significant difference of grains from healthy panicles in all test varieties. The highest estimated productivity was in Inpari 4 variety of $10.378 \mathrm{~kg} / \mathrm{ha}$ and experienced a decrease in production by $35.86 \%$ and the lowest one was Ciherang variety of $8.367 \mathrm{~kg} / \mathrm{ha}$ and experienced a decrease in production by $48.37 \%$ if it was infected by neck blast disease.

\section{ACKNOWLEDGMENT}

Our thanks go to the Agriculture Research and Development Agency of the Ministry of Agriculture for the funding assistance through the DIPA of the West Papua Assessment Institute for Agricultural Technology 
Table 7. Effect of neck blast disease on estimated productivity of milled dry grain in some high yielding lowland rice varieties

\begin{tabular}{lccccc}
\hline \multirow{2}{*}{ Panicle status } & \multicolumn{5}{c}{ Estimated productivity of milled dry grain $(\mathrm{kg} / \mathrm{ha})$} \\
\cline { 2 - 5 } & Ciherang & Inpari 4 & Inpari 7 & Inpari 8 & Inpari 9 \\
\hline Healthy & 8.367 & 10.378 & 9.832 & 8.611 & 9.890 \\
Blast & 4.320 & 6.656 & 6.525 & 5.592 & 5.446 \\
t count value & 8.641 & 5.464 & 2.499 & 2.474 & 5.847 \\
t table value & 2.570 & 2.570 & 2.570 & 2.570 & 2.570 \\
Significant & $*$ & $*$ & $\mathrm{NS}$ & $\mathrm{NS}$ & $*$ \\
\hline
\end{tabular}

to carry out this research to completion. We also express our gratitude to those who have helped in the field data collection to completion.

\section{REFERENCES}

Abebrese SO, Yeboah A, Dogbe W, Dartey PKA, Akromah R, Gracen VE, Offei SK, \& Danquah EY. 2019. Evaluation of yield, reaction to diseases, and grain physical attributes of some introduced rice hybrids in Ghana. International J. Agron. 2019: 1-8.

Ahmadikhah A \& Khosravi V. 2018. Rice grain quality as affected by blast-causing agent (Pyricularia oryzae) along with a molecular analysis of blast resistance at Pi5 and Pi-ta loci. Aust. J. Crop Sci. 12(6): 870-877.

Candole BL, Siebenmorgen TJ, Lee FN, \& Cartwright RD. 2000. Effect of rice blast and sheath blight on physical properties of selected rice cultivars. Cereal Chem. 77(5): 535-540.

Dewi IM, Cholil A, \& Muhibuddin A. 2013. Hubungan karakteristik jaringan daun dengan tingkat serangan penyakit blas daun (Pyricularia oryzae Cav.) pada beberapa genotype padi (Oryza sativa L.). Jurnal HPT. 1(2): 10-18.

Faivre-Rampant O, Geniès L, Piffanelli P, \& Tharreau D. 2013. Transmission of rice blast from seeds to adult plants in a non-systemic way. Plant Pathol. 62(4): 879-887.

Galhano R \& Talbot NJ. 2011. The biology of blast: Understanding how Magnaporthe oryzae invades rice plants. Fungal Biol. Rev. 25(1): 6167.

Ghatak A, Willocquet L, Savary S, \& Kumar J. 2013. Variability in aggressiveness of rice blast
(Magnaporthe oryzae) isolates originating from rice leaves and necks: A case of pathogen specialization? PLoS ONE. 8(6): e66180.

Hai LH, Kim PV, Du PV, Thuy TTT, \& Thanh DN. 2007. Grain yield and grain-milling quality as affected by rice blast disease (Pyricularia grisea), at My Thanh Nam, Cai Lay, Tien Giang. Omonrice. 15: 102-107.

Hao Z, Wang L, Liang J, \& Tao R. 2011. Response of the panicles exserted from the caulis and from various effective tillers at four stages of panicle development to neck blast in rice. Eur. J. Plant Pathol. 131(2): 269-275.

Huang R, Jiang L, Zheng J, Wang T, Wang H, Huang Y, \& Hong Z. 2013. Genetic bases of rice grain shape: so many genes, so little known. Trends Plant Sci. 18(4): 218-226.

IRRI. 2013. Standard Evaluation System for Rice. $5^{\text {th }}$ edition. International Rice Research Institute, Philippines.

Katsantonis D, Koutroubas SD, Ntanos DA, \& Lupotto E. 2008. Effect of blast disease on nitrogen accumulation and remobilization to rice grain. $J$. Plant Pathol. 90(2): 263-272.

Khan MAI, Bhuiyan MdR, Hossain MdS, Sen PP, Ara A, Siddique MdA, \& Ali MdA. 2014. Neck blast disease influences grain yield and quality traits of aromatic rice. C. R. Biol. 337(11): 635-641.

Koutroubas SD, Katsantonis D, Ntanos DA, \& Lupotto E. 2009. Blast disease influence on agronomic and quality traits of rice varieties under Mediterranean conditions. Turk. J. Agric For. 33: 487-494.

Maheshwari R \& Sharma IR. 2013. Prevalence and distribution of blast disease (Pyricularia oryzae 
cav.) on rice plants in paddy growing areas of the Bundi District, Rajasthan. Asian J. Plant Sci. Res. 3(1): 108-110.

Mousanejad S, Alizadeh A, \& Safaie N. 2010. Assessment of yield loss due to rice blast disease in Iran. J. Agr. Sci. Tech. 12: 357-364.

$\mathrm{Ou}$ SH. 1985. Rice disease. $2^{\text {nd }}$ edition. Commonwealth Micological Institute, United Kingdom.

Puri KD, Shrestha SM, Chhetri GBK, \& Joshi KD. 2009. Leaf and neck blast resistance reaction in tropical rice lines under green house condition. Euphytica. 165(3): 523-532.

Singh R, Sunder S, \& Dodan DS. 2013. Estimation of losses in grain yield due to bacterial blight and neck blast of rice in Haryana. Indian Phytopath. 66(3): 249-251.

Skamnioti P \& Gurr SJ. 2009. Against the grain: safeguarding rice from rice blast disease. Trends Biotechnol. 27(3): 141-150.

Subiadi, Sipi S, \& Motulo H. 2016. Estimasi kehilangan hasil padi akibat serangan penyakit blas leher. In:
Sjahbuddin A, Kindangen JG, Taulu LA, Paat PC, Joseph GH, \& Hendayana R (Eds.). Prosiding Seminar Nasional Akselerasi Agroinovasi Berbasis Sumberdaya Lokal Menuju Kemandirian Pangan. pp. 377-385. Balai Besar Pengkajian dan Pengembangan teknologi Pertanian, Bogor.

Sudir, Nasution A, Santoso, \& Nuryanto B. 2014. Penyakit blas (Pyricularia grisea) dan strategi pengendaliannya pada tanaman padi. Iptek Tanam Pangan. 9 (2): 85-96.

Suganda T, Yulia E, Widiantini F, \& Hersanti. 2016. Intensitas penyakit blas (Pyricularia oryzae Cav.) pada padi varietas ciherang di lokasi endemik dan pengaruhnya terhadap kehilangan hasil. Jurnal Agrikultura. 27(3): 154-159.

Wicaksono D, Wibowo A, \& Widiastuti A. 2017. Metode isolasi pyricularia oryzae penyebab penyakit blas padi. J. HPT. Tropika. 17(1): 62-69.

Zulaika Z, Soekarno BP, \& Nurmansyah A. 2018. Pemodelan keparahan penyakit blas pada tanaman padi di Kabupaten Subang. J. Fitopatologi Indonesia. 14(2): 47-53. 